\title{
Gastronomia, Cultura e Mídia: o longo percurso "Você é o que você come"
}

\begin{abstract}
RESUMO
Este texto se refere de uma maneira transversal à pesquisa que estamos desenvolvendo em torno de alguns eixos: corpo e subjetividade; a medicalização da sociedade, a representação pública das ciências nas revistas de divulgação e o imaginário tecnológico. Escolhemos como tema a gastronomia porque participando da relação inicial entre filosofia e medicina, nela reconhecemos a presença de um duplo eixo e de suas tensões na nossa formação ocidental: o uso dos prazeres e o cuidado de si. Na nossa atualidade, onde "a saúde substituiu a salvação", é interessante pensar no contraste entre regras draconianas de cuidado de si e o prestígio dos elementos ligados à imaginação gastronômica, os chefs de cuisine e o que este contraste denuncia da nossa experiência de viver e consumir. Duas formas de conceber o excesso parecem presentes: o supérfluo incensado de um lado e tornado grotesco de outro.
\end{abstract}

\section{PALAVRAS-CHAVE}

Gastronomia

Excesso

Mídia

\section{ABSTRACT}

This article is linked on a transversal way with the research we are developing related to three axes: body and subjectivity, the medicalisation of our society and the public representation of sciences in the scientific magazines and the technologic imaginary. We chose as our subject the gastronomy because participating of the first relationship between medicine and philosophy, we can find there two presences very important to our occidental experience: the use of pleasures and the care of oneself. Nowadays, when health has replaced the salvation, is interesting to think about the opposition between the straight regulations of the care of oneself and the prestige of the imagination connected to gastronomic imagination, the chefs de cuisine and what this contrast shows about our experience of living and consuming. Two forms of conceive the excess seem to be presents: the luxury and the grotesque.

\section{KEYWORDS}

Gastronomy

Excess

Media

\section{leda Tucherman}

Professora do Programa de Pós-Graduacão em Comunicação da UFRJ/RJ/BR.

iedatucherman@gmail.com 
Em certa ocasião o filósofo Michel Serres, bastante conhecido entre nós, fez um comentário: para ele, os pecados haviam emigrado, saindo dos confessionários dos padres para os consultórios dos médicos, o que significava que a punição ou efeito não se daria na outra e eterna vida, e sim nesta, sob a forma de doenças e sintomas. Senão vejamos: luxúria provoca AIDS, inveja dá gastrite, gula causa arteriosclerose podendo levar a infartos e derrames, preguiça gera problemas musculares, ósseos e circulatórios que aparecem como osteoporose, isquemias e outras mazelas, e por aí vai. Pouco depois, numa conversa informal, um amigo psicanalista comentou que, nos dias de hoje, a sobremesa provoca mais culpa do que um adultério.

Certamente isto confirma a aposta que Foucault havia antecipado num pequeno texto dos anos 60 a de que "em nossos dias a saúde substituiu a salvação" (Foucault, 2006, p. 579). Também indica a historicidade da relação do homem consigo mesmo e as diferentes mediações estabelecidas na nossa cultura que podemos observar em campos aparentemente "inocentes" como a alimentação ou a sua forma mais sofisticada, a gastronomia.

Investindo um primeiro olhar sobre o nosso presente encontramos nas nossas formas de comunicação mais mediáticas, a saber, jornais, revistas, programas de TV aberta e a cabo, assim como no cinema e em alguns seriados, um contraste curioso que não poderia deixar de intrigar: por um lado, temos uma coleção de conselhos que dirigem uma conduta ascética, especialmente no que toca aos chamados inimigos, gorduras e açúcares. Por outro, encontramos a celebração de uma figura que, socialmente, foi alçada à máxima elite, comparável aos artistas e inventores, o chef de cuisine.

Este, por sua vez, é secundado pelos críticos gastronômicos, cuja opinião é capaz de elevar seu prestígio (e os preços praticados nos seus restaurantes) ou de lançá-los na ignomínia, (esvaziando seus restaurantes). Não deixa de ser engraçado verificar que o famoso Guide Michelin, que desde 1926 atribui estrelas aos restaurantes é conhecido como o livro vermelho. Mais interessante ainda pensar que o mais famoso livro vermelho que conhecemos era o livro dos pensamentos de Mao-Tsé Tung e toda a carga de autoridade que ele apresentava.

O que é que podemos depreender deste contraste entre evitar comer para viver muito, asso- ciado a um conjunto de medidas restritivas e impositivas, tais como exercícios, exames regulares, autocontrole permanente, e os elogios rasgados, as avaliações de personagens como Ferran Adrià, Joel Reblouchon, e tantos outros?

0 percurso do que conhecemos como a origem das questões relativas à alimentação e à gastronomia nasce numa íntima relação entre filosofia e medicina no nosso berço grego, e pode ser enquadrada por dois eixos que podemos chamar, novamente recorrendo à inspiração foucaultiana, de o uso dos prazeres e o cuidado de si.

Fica mais interessante quando verificamos nas TVs a cabo, o modelo contemporâneo de customização do consumo, a quantidade de programas de alta gastronomia, tais como Cozinhando com Nigella, A Cozinha de Jaime Oliver, Mesa para dois, entre outros. A rigor, estes programas apresentam a gastronomia como cultura, menos ligada ao seu aspecto utilitário e mais às descobertas de requintes sensoriais e sociais. ${ }^{1}$

Mesmo em termos de reality-show, entre os muitos formatos que temos circulando, aparece um, Você é o que você come, quase um circo de horrores, que mostra sempre uma família obesa, observada por uma nutróloga que coloca numa mesa o que esta consome numa semana, provocando enjoo em qualquer telespectador sensível.

Bom, dirão os eventuais leitores deste texto, qual o interesse desta apresentação? A resposta é que, com deslocamentos acentuados, porém tendo genealogias reconhecidas, o percurso do que conhecemos como a origem das questões relativas à alimentação e à gastronomia nasce numa íntima relação entre filosofia e medicina no nosso berço grego, e pode ser enquadrada por dois eixos que podemos chamar, novamente recorrendo à inspiração foucaultiana, de o uso dos prazeres e o cuidado de si $^{2}$.

De início é interessante verificar um movimento: estudando a história da sexualidade e as "técnicas de si", vemos surgir algo que corresponde a uma relação do indivíduo consigo mesmo, que compreende um conjunto de reflexões e de práticas que constituem, ao mesmo tempo, uma moral, uma dietética, uma erótica e uma estética da existência. Portanto, desde o mais remoto princípio, podemos encontrar uma relação 
entre gastronomia e erótica, uma associação virtuosa (neste momento) no campo dos prazeres.

\section{Entrando no tema}

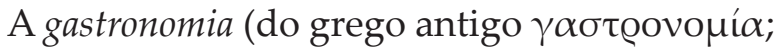
$\gamma \alpha \sigma \tau \varrho o ́ \varsigma$ ["estômago"] e vouí $\alpha$ ["lei"|"conhecimento"] ) é um ramo que abrange a culinária, as bebidas, os materiais usados na alimentação e, em geral, todos os aspectos culturais a ela associados. Esta é a definição clássica, que, de imediato, associa a parte relativa aos alimentos e o contexto onde esta gastronomia se apresenta.

Já a definição filosófica foi proposta por Brillat-Savarin, um iluminista, que escreveu um famoso livro, A Fisiologia do Gosto ${ }^{3}$, buscando construir o que ele apresenta como uma filosofia ou uma ciência da gastronomia. A definição nos parece preciosa:

A gastronomia é que nos sustenta, do nascimento ao túmulo, que faz crescer as delícias do amor e a confiança da amizade, que desarma o ódio, facilita os negócios e nos oferece, na curta trajetória de vida, o único prazer que não se acompanha de fadiga e ainda nos descansa de todos os outros (Brillat-Savarin, 1995).

Portanto, temos um quadro que sugere algumas palavras-chave: natureza e cultura; rituais e vínculos. Comecemos pelos rituais: na nossa dupla origem, judaico-cristã e grega, construímos uma forma de ser a partir de um primeiro movimento fundamental: o abandono do consumo da carne crua sacrificial, no mundo pitagórico como no das Leis de Moisés. Passando do cru ao cozido e a todas as formas de intervenção humana. Começamos aí a fazer cultura, isto é, artificializar a natureza ${ }^{4}$.

O próprio da cultura é seu modelo de organização: na tarefa de "inventar" o homem que as nossas duas origens enfrentaram, precisando diferenciá-lo dos animais e dos deuses: foi na relação entre a vida como permanência e expansão que a filosofia e a medicina constituíram um campo conexo, que tratava da vida e que tinha na dietética o seu eixo mais visível.

Assim o mundo clássico se estabeleceu como domínio da civilização, portanto na diferença dos outros, bárbaros. Desde Homero, na Ilíada, vemos os homens, comedores de pão e bebedores de vinho: néctar e ambrosia para os deuses. Há uma diferença entre os homens e os deuses, assim como entre os homens e as bestas: talvez possamos dizer que o nascimento do homem se deva mais a esta primeira definição do que ele não é do que a uma explicitação do que o constitui.

\section{Gastronomia na antiguidade clássica}

Qual seria o bom uso do Banquete? Na maior parte das vezes é proibido às mulheres e aos escravos, dirigido, portanto aos cidadãos livres. Acontece nos santuários, ou espaços a isto destinados nas polis, embora possa ser improvisado e se realizar onde couberem os convivas. Era dividido em duas partes: o convivium, a parte das comidas e o symposion a segunda e mais importante parte, a das bebidas. Os convivas faziam estas refeições estendidos em divãs, diante dos quais eram postas mesas amovíveis. O corpo é apoiado num cotovelo que era pousado numa almofada, há pouca louça, come-se com as mãos e o resto é lançado ao chão; são os escravos que se encarregam do serviço.

O symposion teve várias funções, políticas inclusive. Mas até o limiar do helenismo a poesia dá ao symposion a sua significação profunda. A poesia narra a cerimônia do vinho no momento em que acontece; a mesma poesia, via aedo, lança uma ponte entre o presente e o passado. $\mathrm{O}$ symposion será o patrimônio poético grego. No correr do século IVAC, o symposium passa a ser também palco das discussões filosóficas. O diálogo que conhecemos como $O$ Banquete, de Platão, chamava-se originalmente Symposion.

Estes banquetes, no início, eram ligados aos rituais religiosos. Cada vez mais, depois do surgimento da polis, modificam seu caráter concreto e simbólico, aproximando-se da definição e da representação do sistema político, segundo modalidades de uma sociedade completamente diferente. Aí estamos falando da diferença radical dos bárbaros, e de um novo conjunto lógico que vai de gradação em gradação: excluído da sociabilidade do banquete, excluído da polis, da civilização grega e da humanidade.

Para lembrarmos que a comida ou a dietética era um dos traços da cultura grega, aí incluídas a medicina e a filosofia, encontramos em Galeno, no século II d.C. a seguinte afirmação: “Não temos necessidade o tempo todo de outras ajudas, mas sem a alimentação, nem os homens saudáveis nem os doentes podem viver".

De qualquer modo, a alimentação na Grécia mantinha também a memória construída por Homero: os homens são comedores de pão e bebedores de vinho. O que definia também a 
medida justa de uma propriedade como sendo o quinhão de terra que oferece tudo de que necessita um homem da natureza: trigo, óleo, vinho, figos e os laticínios de cabras e ovelhas aos quais se acrescentava o peixe cru ou em conserva. A carne era valorizada embora relativamente rara e os animais domésticos tornavam-se necessários mais pelo leite, pela lã, e pela ajuda no trabalho doméstico do que para o consumo.

A cozinha e a dietética cabem no mesmo universo semântico fazendo desta origem da gastronomia um universo complexo em que a técnica, os gestos, a ciência e a cultura remetem uns aos outros, associando-se às predileções gratuitas, às paixões cegas e ao pequeno grau de loucura e intensidade que nunca se ausenta da vida e põe em cheque as normas rígidas do sistema cultural. São as presenças celebradas e temidas de Baco e Afrodite, dois deuses, vale lembrar, nesta onda de prazeres. Que faz tensão com "a justa medida", o ideal ético-estético dos gregos.

Dizendo de outro modo, coube ao homem construir uma vida num duplo eixo: primeiro fala de um cuidado de si, que fez na Grécia surgir o ideal de uma civilização de mens sana in corpore sano; o segundo se debruça sobre o uso dos prazeres, que, nesta moral assimétrica e livre, não será negado nem reprimido; deve ser controlado. É fundamental entender esta antiga presença da ideia de prazer como revitalizante; sem precisar ir muito longe, Platão, símbolo desta construção escreve o seu diálogo que já mencionamos $\mathrm{O}$ Banquete, invocando a presença da comida, do vinho e dos belos corpos dos jovens atenienses para falar do Amor e do Bem.

Seguindo a cronologia da antiguidade clássica, a experiência romana terá suas especificidades: uma dualidade curiosa de dois ideais, o de frugalidade pessoal e hospitalidade pródiga. Contraste sintetizado na vida de um romano comum: o prandium, primeira refeição do meio-dia, muitas vezes era pouco mais do que as sobras do dia anterior, comidas de pé; seu propósito era encher a barriga para seguir os afazeres do dia, o negocium. A cena ou sua forma mais grandiosa, o convivium, era uma refeição substancial e podia culminar com uma série copiosa de pratos cozidos, comidos numa posição reclinada, junto com os convidados. O tempo da cena era o do ócium, depois das atividades quando a criatura podia ingerir as ricas iguarias por puro prazer ${ }^{5}$.

Quando Roma passou de república a capital de um vasto império, cresceu simultaneamente o campo das vaidades: as iguarias do mundo conhecido corriam para Roma e estavam à disposição de quem podia pagar por elas, marcando um acentuado contraste entre uns e outros. A ideia de diferenciação social pela capacidade de consumo na gastronomia é, como vemos, muito antiga.

\section{0 mundo cristão}

O mundo religioso, que se afirmou com a vitória do cristianismo, trouxe um discurso novo, centrado sobre dois elementos ausentes anteriormente: o primeiro era a ideia de fim de mundo e apocalipse, estranha ao pensamento greco-romano, que se pautava pelo modelo do eterno retorno, o segundo foi, neste novo contexto, a criação da associação do prazer com o pecado. Esta busca de fazer calar o corpo fez aparecer uma curiosa figura representada pelos anacoretas do deserto, para quem o corpo era um campo de provas de privações na ânsia da graça eterna.

Tal relação de prazer e pecado não desapareceu do nosso mundo e tem sido muitas vezes associada exatamente à gula, primeiro passo para o segundo e mais grave pecado que será a luxúria. Se tivermos um pouco de atenção, gula e luxúria são pecados do corpo e do excesso; os outros pecados são da alma, se aceitarmos a divisão proposta pelo pensamento religioso.

\section{A mesa comunitária}

Neste mundo, o advento do cristianismo e das festas comunitárias trouxe outra luz à questão da hierarquia da comida. Esta deveria, em princípio, se atrelar à antiguidade da adesão à vida comunal cristã, e ao papel desempenhado em tal comunidade; e até o século II a casa serviu à comunidade cristã; depois os fiéis a transferiram para outros lugares: entre quatro paredes os fiéis se protegiam e à sua fé cuja prática pública era proibida.

Vários historiadores pensaram que todos os fiéis viriam de classes inferiores, hoje se sabe que provinham também das classes média e alta e se recolhiam com medo de perseguições. Isto criou problemas estratégicos para os fundadores da Igreja: o Apóstolo Paulo teve que encontrar uma fórmula para as reuniões em que os ricos e seus amigos recebiam melhores comidas do que os de status mais baixo: resolveu o problema fazendo os ricos comerem privadamente ${ }^{6}$.

Abrigados, estes emergentes cristãos, organizavam espacial e temporalmente sua rotina religiosa: sua jornada de fé começava na sala 
de jantar; nela dividia-se a refeição e durante as mesmas os crentes rezavam, conversavam e liam as cartas dos correligionários residentes em lugares distantes do Império. Esse ambiente propiciava apoio emocional às experiências intensamente individuais que abrigava. Como lembra São Paulo, o redor da mesa evocava a Santa Ceia.

Segundo palavras de um historiador da Igreja, as refeições domésticas eram fundamentais porque o próprio ato de comer sinalizava as relações sociais. $\mathrm{O}$ encontro nas refeições era chamado de ágape, palavra que pode ser traduzida por celebração de companheiros, koionia segundo a Bíblia.

O código de valores cristãos também alterou a disposição dos lugares à mesa: pelo costume romano a pessoa mais importante sentava-se no extremo do aposento, enquanto os demais se alinhavam a partir deste ponto, em escala descendente. A ágape cristã rompeu esta ordem, distribuindo as pessoas segundo a antiguidade e intensidade de sua fé; postulantes e recémbatizados na entrada e apenas cristãos ao redor da mesa. "Os impulsos da natureza estão em guerra com os impulsos do espírito", escreveu Santo Agostinho em suas Confissões, discorrendo sobre o que sentiu durante uma festividade em que o cheiro da comida e as emanações do álcool o tentaram. Neste sentido, para o ideal do mundo cristão, a comunhão na mesa era o afeto importante, a relação sensória o que não devia se cultivado.

Na verdade, este momento do triunfo do cristianismo viveu ainda uma aliança entre uma concepção de saúde ligada à dietética e esta moral religiosa: assim era perigoso do ponto de vista moral e médico consumir alimentos que pudessem provocar um aquecimento excessivo do organismo que levava os imprudentes diretamente do pecado da gula para o outro, ainda mais grave, da luxúria.

Neste universo cuja crença médica vigorou até o século XVII, 1628, quando apareceu a obra de William Harvey, De Motu Carbis, a imagem modelo do corpo era ligada ao princípio de um equilíbrio no aquecimento natural do corpo. $\mathrm{O}$ que Harvey descobriu parece muito simples: o coração bombeia o sangue através das artérias do corpo, recebendo-o de volta das veias, para ser bombeado. É da circulação que vem o calor.

Antes, como se acreditava numa alteração vinda do exterior da temperatura, tratados e compêndios da época mencionam que as mulheres viúvas não devem comer as mesmas aves que comiam quando tinham maridos, e menos ainda as moças solteiras devem consumir cebolas, pimentas e chocolate, estes últimos já ligados aos novos ingredientes chegados das conquistas das colônias. Estes elementos estimulantes "aumentariam o calor" e fariam falar alto as vozes do corpo, que deviam calar-se: resumindo, vinculam-se ao território dos prazeres.

\section{Pensando nos prazeres}

Está na hora de pensarmos nas relações dos prazeres, afinal, o prazer certamente não é menos legítimo do que a virtude e pode encantar muito mais. Prazer este que tem dois pontos em contato muito próximos com o cerne da gastronomia: a imaginação que nos conduz aos afrodisíacos e o excesso que também pertence à métrica da gastronomia, quando a olhamos a partir do ponto de vista utilitário.

Como definir um afrodisíaco? Trata-se de uma substância ou atividade que desperta o desejo amoroso. Alguns dos alimentos considerados afrodisíacos têm um fundamento científico para explicar a sua associação, mas a maioria nos afeta por movimentos provocados pela nossa imaginação: cada pessoa e cada cultura reage de sua própria maneira diante deles.

Como lembra Isabel Allende no livro Afrodite, os afrodisíacos são a ponte entre a gula e a luxúria os dois únicos pecados capitais que tem estilo, os outros sendo da maledicência e do quebranto. Talvez seja possível ir um pouco mais longe: nas premissas dos afrodisíacos como da gastronomia, encontramos a presença desejada do excesso. Assim, se a alimentação foi desde sempre baseada numa economia utilitária uma vez que o corpo foi há muito concebido como uma máquina que precisa de energia, que viria dos alimentos, a gastronomia nunca ficou referida à necessidade.

$\mathrm{Na}$ verdade, a gastronomia passa bem longe do caráter utilitarista. No imaginário gastronômico a refeição aparece, ao mesmo tempo, como forma de prestígio para quem é convidado e demonstração de generosidade de quem convida. Trata-se de uma forma de unir as pessoas e trocar culturas: através das comidas os povos se unem e trocam um pedaço de suas culturas, retomando a lógica que Marcel Mauss encontrou nas sociedades primitivas e desenvolveu tão brilhantemente no seu Ensaio sobre a dádiva, de 1924, onde elaborou sua teoria sobre o dom. $\mathrm{O}$ que ele defende é que, ao contrário do que afirmavam os historiadores, as sociedades não se organizam exclusi- 
vamente em função do mercado, mas, sobretudo, em torno de trocas simbólicas não utilitaristas: favores, presentes, convites. "Nas sociedades primitivas a regra fundamental não repousa sobre contratos, mas sobre três obrigações complementares: dar, receber e retribuir" (Mauss).

Podemos nos permitir uma reflexão: são inúmeros os exemplos que o cinema nos deu, assim como a literatura, desta métrica da gastronomia com uma economia simbólica, e com a conquista do prestígio (Vatel, o filme sobre o cozinheiro do nobre, que queria impressionar o rei Luís XIV é um exemplo cabal) ou com a simples generosidade: Chocolate, Como Água para Chocolate, A Festa de Babette, etc. O que também se verifica nestes exemplos que escolhemos é um investimento de tempo, uma doação da própria atenção, do desejo de dar prazer que é a primeira regra, enunciada ou não, do mundo dos afrodisíacos: fazer desejar é a regra, não?

Neste caso vale menos do que o que aproximava a gastronomia dos pecados da gula e da luxúria; o que conta vinculado ao status e ao luxo do que propriamente ao prazer ou à sensorialidade.

\section{Gastronomia no mundo moderno}

Vários fatores concorreram para que esta relação de cuidados estéticos e éticos que caracteriza a gastronomia, assim como sua relação com o universo das experiências e do prazer se afirmasse no mundo moderno. $\mathrm{O}$ primeiro dado, evidente, a partir das grandes navegações, foi a entrada na Europa não apenas das especiarias já conhecidas (sabemos que já no século XII os comerciantes florentinos já importavam toneladas de pimenta), mas de outra grande gama de produtos que foi aos poucos se incorporando nos hábitos alimentares, sobretudo das elites já que, por virem de outras terras eram caros e raros e marcavam no seu consumo esta diferença.

Além da malagueta africana, do cravo da Índia, da noz moscada, já conhecidos, mas não tão difundidos, a conquista das Américas trará a batata (depois a base da alimentação europeia), o milho, o tomate, o café, o chocolate. Também aí aparece o açúcar, cuja cultura também nos marcou como colônia e gerou uma sociedade particular, aquela que Gilberto Freyre tão em descreveu em Casa Grande e Senzala.

Por outro lado, nesta época, a própria medicina como ciência começa a incorporar as conquistas das ciências experimentais, sobretudo da quí- mica, liberando a comida para o gosto mais do que para o tratamento de saúde. Assim, da Idade Média até o século XVII a alimentação das elites era próxima de uma dietética, das recomendações médicas: na metade do século XVII, início do XVIII, cozinheiros e gastrônomos começaram a falar da harmonia dos sabores. Este afrouxamento que está surgindo pela afirmação da ciência, liberou a gulodice e agora os refinamentos não visam mais manter a boa saúde das pessoas, mas satisfazer o gosto dos que agora se apresentam como peritos na arte de reconhecer iguarias.

Assim, em meados do século XVII (certamente ligado à filosofia empirista e à necessidade de conhecer o homem a partir da sua percepção e imaginação) o gosto começa a ser supervalorizado, gerando mesmo uma teoria que aplica a noção de gosto para a literatura, a comida, o vestuário, o mobiliário, a escultura, a pintura, etc., considerando que é o que distingue o belo do feio, o bom do mau, etc., e é o órgão característico do "homem de gosto", o avatar do homem perfeito.

Também uma literatura que exalta o vinho, além de uma literatura culinária começa a aparecer mostrando um lugar de destaque na cultura para o comer e o beber. Para avaliarmos o grau de importância da discussão sobre o gosto; no movimento iluminista (muito provocado pelo fausto ostensivo das monarquias absolutas) Voltaire escreve no seu Dicionário Filosófico: "Como o mau gosto em nível fisiológico consiste em só se deleitar com temperos muito picantes e elaborados, assim o mau gosto em artes consiste em só se comprazer com ornatos rebuscados e não apreciar a beleza natural".

Nasce aí um livro fundamental e um personagem, seu autor. Estamos falando de A Fisiologia do Gosto, de Brillat-Savarin, ao qual já fizemos referência, que pretende criar a ciência da gastronomia. Além de um valioso estudo de alimentação e de uma "metafísica dos costumes", acompanha-se de uma seleção de receitas comentadas. Vale à pena consultar suas premissas:

a) Os conhecimentos gastronômicos são necessários a todos os homens, pois tendem a aumentar a soma de prazeres que lhes é destinada.

b) Agastronomia social reúne a elegância ateniense, o luxo romano e a delicadeza francesa, que planeja com sagacidade, faz executar com cuidado, saboreia com energia e julga com profundidade (Brillat-Savarin, 1995). 
Também dele podemos citar um comentário que, além de ser delicioso, demonstra uma relação entre gosto e consumo no campo da nascente gastronomia; segundo Savarin, tanto Buffon quanto Voltaire foram grandes consumidores de café; "talvez devessem a este hábito, o primeiro a clareza admirável que se observa nas suas obras; o segundo a harmonia entusiástica de seu estilo".

A partir de então, escrever sobre culinária ou apresentar nos livros receitas e descrições foi recorrente na literatura do século XIX e XX: vê-se em Alexandre Dumas, o criador da Dama das Camélias, que escreveu um Dicionário de Culinária, em Eça de Queirós, em Camilo Castelo Branco, em Balzac, Flaubert, Stendhal, Machado de Assis, e muitos mais, culminando com a madeleine de À la Recherche du Temps Perdu de Proust, assim como suas descrições dos universos dos burgueses Verdurin e dos Duques de Guermante e a diferença de suas mesas.

Outra relação entre literatura, gastronomia e prazer nos é bem descrita por Isabel Allende no seu livro Afrodite. Lá ela nos lembra de buscar desde os salmos de Salomão na Bíblia até a literatura recente, incluindo os Trópicos de Henry Miller, a poesia de Pablo Neruda, além de toda a tradição oriental, como estes autores, em infinitas metáforas poéticas, transformaram a comida em inspiração sexual.

Duas de suas considerações:

um jantar bem pensado é um crescendo que começa com as notas suaves de uma sopa, passa pelos arpejos delicados da entrada, culmina com a fanfarra do prato principal, seguido finalmente dos doces acordes da sobremesa. O processo é comparável ao de fazer amor com estilo, começando com insinuações, saboreando os jogos eróticos, chegando ao clímax com o estrondo habitual e por fim deslizando num afável repouso.

Apetite e sexo são os grandes motores da história, preservam e propagam a espécie, provocam guerras e canções, influenciam religiões, leis e arte. Toda criação é um processo ininterrupto de digestão e fertilidade (Allende, 2007).

\section{Gastronomia e sociabilidade}

Neste conjunto de civilizar o comportamento e cultivar ou reprimir a relação com o prazer, a mesa vai marcar o lugar primordial de sociabili- dade, assim como o espaço onde se encaixam o corpo e a alma, a matéria e o espírito, a exterioridade da etiqueta e a interioridade da ética - o comportamento é regido por uma dupla preocupação: trata-se de controlar e conter os movimentos do corpo e zelar e guiar os da alma. Significa dizer que tanto o início de certas práticas de higiene e estética social, quanto cuidados com aspectos emocionais participavam destes guias de comportamento.

Sem fazer um panorama histórico cronológi$\mathrm{co}$, nos interessa pensar em algumas passagens: especialmente às ligadas a mudanças na maneira de conceber as relações entre a natureza e a cultura; os homens e as mesas. Como exemplo, no reino de Carlos Magno, aos camponeses era permitida a carne cozida, os assados, grelhados diretamente sobre o fogo, sendo privilégio dos nobres. E a explicação para a diferença era que o uso do fogo sem a mediação da água (que se usa para o cozido) ou de recipientes domésticos dava a esta nobreza guerreira uma relação estreita com a força da vida selvagem.

Ao mesmo tempo, havia um limite sutil que separava o que era suficiente, sem grandes ostentações, de pratos excessivamente modestos, portanto inadequados ao nível da família ao qual eram servidos ou ao acontecimento em que estavam envolvidos, nascimento, casamento, sagração de cavaleiro, morte. Nas cidades-estado italianas havia leis suntuárias, assim como em outras cidades da Europa, que cuidavam de reprimir ou penalizar uma excessiva ostentação de riqueza. Mas a avareza também era condenável. Importante é a codificação estreita que acompanha todo ritual.

Também a sociabilidade era uma codificação complicada, marcada por duas regras: amitia e conjuratio. Amitia: nobre, seguida de um juramento, quando um rei ou um nobre pretendia aumentar seu círculo de confiança; a conjuratio, parecida com a amizade jurada, era comum tanto nas classes sociais da nobreza quanto nos grupos sociais situados num nível mais baixo da escala social que selavam esta ligação a fim de resolver problemas.

Nesta lógica, refeições e banquetes funcionavam como rituais criadores de confiança no momento em que se formava a aliança. Os convivia podiam se prolongar por oito dias. Bem antes dos almoços de negócios a mesa funcionou para fazer alianças, planejar anexações de terra, casamentos e guerras. 


\section{O Grande Momento: A Mesa dos Reis}

Falar em rituais, luxo e codificação remete às cortes absolutistas européias, em especial a francesa, o mais acabado exemplo deste universo. Herdeiras dos amitia tornaram-se tão suntuosas que podemos chamá-las de festins. A festa requeria uma produção de tal natureza que os homens que presidiam tais festins ganhavam fama e glória já que precisavam ter, como lembra BrillatSavarin (1995), um número infinito de qualidades: "o gênio para inventar, o conhecimento para decidir, o julgamento para proporcionar, a sagacidade para descobrir, a firmeza para se fazer obedecer, a pontualidade para não fazer esperar."

Não apenas a comida, mas as danças, os quadros e esculturas produzidos pela maneira de dispor os alimentos (um desafio para as naturezas mortas), os fogos de artifício, etc., passam a ser da lógica da mesa real. Olhando com nossos olhos este destempero de ostentação é absurdo: mas através dele vimos evoluir um conjunto de ocupações científicas e artesanais que alteraram a relação natureza-cultura de uma maneira radical.

\section{Gastronomia e seus utensílios: sabores, saberes e fazeres}

Seria uma incongruência falarmos em sofisticação sem observarmos as mudanças na forma como a comida foi feita, apresentada e percebida; seria igualmente impróprio não o relacionar com um universo de transformações na cultura ocidental que engloba um conjunto de condições materiais e teóricas; assim, sabemos que a mão foi o primeiro utensílio utilizado, mas esta era auxiliada por pedras para cortar e triturar alimentos e paus para mexer o fogo. Aliás, o uso do fogo para cozinhar tornou-se possível por causa da cerâmica, assim como foi com a descoberta da metalurgia que surgiram garfos e facas, a colher mantendo-se de madeira ainda por algum tempo.

Neste universo, as facas foram os primeiros utensílios; sua presença é já confirmada na Idade de Bronze (6.500 anos antes de Cristo) na Ásia Menor e seu uso era duplo, servia tanto para cortar os alimentos como para levá-los à boca. Seu uso refinado tornou-se possível e visível com o surgimento de famosas cutelarias na Europa.

A chegada do garfo na Europa, parece datar do século XI, quando aportou em Veneza pelas mãos de princesa Teodora, filha de Constantino VIII, imperador do Oriente, que trouxe um garfo de ouro de dois dentes, para comer frutas; o costume se espalhou e no século XV já era bastante conhecido na Itália. Na Inglaterra, contudo, só chega no século XVII,e, em Portugal seu uso só começou a se difundir na corte em 1836.

No mesmo passo, associando-se a saberes que alteram as condições materiais e expandem os limites, como já mencionamos, a física e a química não apenas cuidaram da digestão como também se ocuparam de introduzir aperfeiçoamentos, desde a panela do operário até os extratos transparentes dos copos de cristal. A arte de conservar alimentos foi desenvolvida, permitindo o rebuscamento dos pâtisseurs e confeiteiros, a horticultura evoluiu muitíssimo com o uso das estufas aquecidas, o cultivo dos vinhos foi aperfeiçoado e o café torna-se popular, de manhã como alimento, à noite como bebida estimulante e tônica.

Tudo isto contribuiu para que se instalasse uma real gastronomia um hábito que se lançou tanto no mundo do convívio social normal, ou seja, o de receber e alimentar quanto no do novo universo público, que são os banquetes políticos, mas, sobretudo os cafés e restaurantes que começam a proliferar.

Apesar das pousadas e tavernas serem conhecidas desde a antiguidade estes estabelecimentos eram voltados a viajantes e, em geral, o povo das suas cidades raramente se alimentavam lá. O restaurante se firmou na França após a Revolução Francesa destituir a aristocracia, deixando um contingente de serviçais hábeis no trato com os alimentos, ao mesmo tempo em que muitos provincianos chegavam à cidade sem pessoas para cozinhar para elas, nem cartas de apresentação às famílias locais. $\mathrm{O}$ encontro desses dois públicos deu origem ao hábito de se fazer refeições fora de casa.

Estes espaços públicos trazem uma nova possibilidade capitalista e burguesa que vai acrescentar um dado à relação entre homens e mesas: a liberdade e a individualidade. Assim, embora comer continue (até os nossos dias) a ser um ato social, novas escolhas se tornam possíveis.

\section{Restaurantes}

O termo restaurante (do Francês restaurer, restaurar) surgiu no século XVI, com o significado de "comida restauradora", e se referia especificamente a uma sopa. O uso moderno da palavra surgiu por volta de 1765 quando um parisiense conhecido por Boulanger (padeiro em francês) abriu seu estabelecimento. O primeiro restauran- 
te como o conhecemos (com clientes escolhendo porções individuais em um cardápio, aguardando em suas mesas, com horários fixos) foi o Grande Taverne de Londres, fundado em 1782 por Antoine Beauvilliers, na rua de Richelieu, em Paris,que permaneceu 20 anos sem rival. E serão os restaurantes que farão do próprio Beauvilliers e de Antonin Carême (8 de Junho, 1784-12 de Janeiro, 1833), aquilo que a história lhes consagrou: o inventor da moderna culinária francesa, a saber, o cozinheiro dos reis e o rei dos cozinheiros. Se o primeiro deve sua fama ao estabelecimento que criou, o segundo será a primeira lenda do mundo gastronômico e o patrono, por assim dizer, dos nossos mencionados chefs-de-cuisine.

Carême ganhou fama em Paris por suas pièces montées, composições elaboradas usadas como arranjos de centro, os quais Bailly exibia na vitrine da pâtisserie. Essas peças eram muitas vezes, altas e feitas de material comestível como açúcar, marzipan, e massa. Ele as modelava como templos, pirâmides e ruínas antigas, extraindo ideias de livros de arquitetura histórica, os quais ele lia na Bibliothèque Nationale.

Começou sua carreira na gastronomia como empregado do diplomata e nobre Talleyrand e, conta a lenda, que o chanceler Talleyrand propôs um teste a Carême: criar um menu para o ano inteiro, sem repetição e usando apenas os produtos da estação. Carême passou no teste. Neste sentido, mais do que um empregador ou patrocinador, Talleyrand encorajou Carême a produzir um novo e refinado estilo de gastronomia, usando ervas e vegetais frescos e simplificando molhos com o uso de menos ingredientes. A mesa de Talleyrand tornou-se famosa durante as negociações que se seguiram após a queda de Napoleão, no Congresso de Viena. Quando o Congresso acabou, tanto o mapa da Europa quanto os gostos culinários das classes mais altas foram totalmente modificados.

Seu impacto na gastronomia deu-se tanto no trivial, quanto no teórico. Credita-se a ele a criação do tradicional chapéu de chef, o Toque; ele criou novos molhos e pratos e publicou uma classificação de todos os molhos em grupos, baseado em 4 molhos básicos. Carême escreveu diversos trabalhos em gastronomia, sobre L'Art de la Cuisine Française (5 volumes, 1833-34), que incluíam, além de centenas de receitas, planejamento de cardápios, uma história da culinária francesa e algumas precisas instruções de como organizar uma cozinha. Fundou, portanto, a literatura propriamente culinária, que desde então terá presença constante nas coleções editoriais que surgirão no seu rastro.

\section{As grandes mudanças}

Vamos ressaltar alguns dados: vida urbana, movimento capitalista, liberdade de escolha, novos espaços público-privados, associado ao que também fez parte deste movimento e deu a ele o seu tom: o surgimento dos jornais, que neste momento representam o rompimento com a tradição e os costumes, produzindo opiniões ligadas ao presente, à política, à vida cotidiana, aos novos aspectos da cidade. Não é sem motivo que embora o jornal seja uma leitura individual, seja significativo o número de pessoas que o lêem nos cafés. É uma curiosa forma de viver num universo que, podemos chamar, usando a licença com uma aplicação extemporânea de um privadocoletivo. Casos muito escandalosos, notícias mais contundentes ou simples faits-divers acabam pautando as conversas dos cafés, remetendo à sua origem de crítica política.

\section{A segunda diferenciação social}

Assim a comida viveu dois períodos de diferenciação social: a primeira tinha a ver com a quantidade e a concentração dos víveres nas mãos de alguns; agora, com a gastronomia, o "poder de compra" corresponde a um "poder de deleite", a cultura trazendo este luxo para a vida cotidiana, já que a estratificação social hoje nos reconhece como tipos de consumidores: escolher um restaurante já é uma posição. Que não precisa ser fixa.

\section{Assim a comida viveu dois períodos de diferenciação social: a primeira tinha a ver com a quantidade e a concentração dos víveres nas mãos de alguns; agora, com a gastronomia, o "poder de compra" corresponde a um "poder de deleite"}

Podemos pensar então, para começar um diagnóstico sobre a gastronomia, que embora tenha realmente acontecido com a ascensão da burguesia, ela remete a dois elementos não relevantes para a lógica burguesa: o excesso, do qual falamos muito na segunda passada e um desligamento quase radical da lógica utilitária. É assim 
que trufas, caviar, alguns azeites, vinhos, carnes especiais, peixes, são bens de consumo relacionais, posicionais, símbolos de um status sem correspondência na regra normal dos bens.

Neste processo, neste nosso presente vivemos um predomínio das ciências ditas da vida como as capitãs do progresso, beneficiadas por três fatores fundamentais que encontramos a partir dos anos 60, a saber: o investimento massivo na indústria dos fármacos; as promessas contidas nas descobertas possíveis da genética e o progresso dos instrumentos de visibilidade e exame. Estas biotecnologias elaboram uma cultura radical do cuidado de si e da boa gestão do corpo e da aparência, a gordura sendo agora não uma característica, mas um descuido ou um crime, dependendo do meio em que se apresenta. Indo mais longe, esperam dos alimentos algo além da sua primitiva função: devem combater radicais livres, auxiliar nos processos de retardamento do envelhecimento, proteger de doenças, enfim, precisam provar efeitos terapêuticos. É isto o que conta hoje, muito mais do que a cota de prazer ou lembranças que possamos buscar em algum prato.

Mas excesso é excesso: por isto mesmo pode aparecer positivado e incensado, como no caso do chef-de-cuisine. Ou numa outra relação entre literatura, gastronomia e prazer que é bem descrita por Isabel Allende no seu livro Afrodite. Lá ela nos lembra de buscar desde os salmos de Salomão na Bíblia até a literatura recente, além de toda a tradição oriental, como estes autores, em infinitas metáforas poéticas transformaram a comida em inspiração sexual. Vejamos duas de suas considerações:

Um jantar bem pensado é um crescendo que começa com as notas suaves de uma sopa, passa pelos arpejos delicados da entrada, culmina com a fanfarra do prato principal, seguido finalmente dos doces acordes da sobremesa. O processo é comparável ao de fazer amor com estilo, começando com insinuações, saboreando os jogos eróticos, chegando ao clímax com o estrondo habitual e por fim deslizando num afável repouso (Allende, 2007, p. 236).

Apetite e sexo são os grandes motores da história, preservam e propagam a espécie, provocam guerras e canções, influenciam religiões, leis e arte. Toda criação é um processo ininterrupto de digestão e fertilidade (Allende, 2007, p. 207).
$\mathrm{Ou}$, ao contrário, condenado ao grotesco, como em Você é o que você come. Neste caso, associação se dá num nível muito próximo da escatologia. Portanto, podemos voltar à velha máxima: o excesso passa por uma linha fina, como um papel de seda; vira lixo ou luxo, segundo se ligue a este ou aquele princípio. E, portanto, assim é o que parece. Ou aparece na telinha da TV e na nossa imaginação.

\section{REFERÊNCIAS}

ALLENDE, Isabel. Afrodite. Rio de Janeiro: Bertrand Brasil, 2007.

BRILLAT-SAVARIN, Antoine. A fisiologia do gosto. São Paulo: Companhia das Letras, 1995.

FLANDRIN, Jean-Louis; MONTANARI, Massimo. História da alimentação. São Paulo: Estação Liberdade, 1998.

FOUCAULT, Michel. A Hermenêutica do sujeito. São Paulo: Martins Fontes, 2006.

JAEGER, Werner. Paidéia: a formação do homem grego. São Paulo: Martins Fontes, 1986.

KRONDL, Michael. O sabor da conquista: Veneza, Lisboa e Amsterdam na rota das especiarias. Rio de Janeiro: Rocco, 2003.

SERRES, Michel. Éclaircissements. Paris: Flammarion, 1992.

Hominescência. Rio de Janeiro: Bertrand Brasil, 2003.

TUCHERMAN, Ieda. Breve história do corpo e de seus monstros. Lisboa: Veja, 1999.

\section{NOTAS}

1 Não nos parece ser o mesmo caso, por exemplo, de programas da TV aberta, como é o caso do Mais_Você da Ana Maria Braga. Ela é conhecida como uma apresentadora, e a parte de culinária do seu programa tem outro caráter, preocupando-se, como é natural, com o público que o assiste.

2 Estamos nos referindo ao título dos volumes II e III da História da Sexualidade.

3 O livro de Brillat- Savarin teve vital importância: um iluminista que incorporou a gastronomia definitivamente como um objetos nobre para o pensamento e base para uma teoria das percepções e sensações. Desenvolveremos mais tarde.

4 A esta interdição radical, seguiram-se outras, segundo as regras dispostas por cada uma das religiões e culturas, o que poderia nos levar a dizer também que o que não se pode comer marca a pertinência a um grupo: judeus com carne de porco, muçulmanos com bebidas alcoólicas.

5 Certamente não no mesmo contexto, mas marcando uma significação diferenciada segundo a hora do dia e o objetivo da refeição, ainda consideramos que refeições diurnas, como o almoço, referem-se ao mundo do trabalho e dos negócios, ao passo que as refeições noturnas, jantares, etc., marcam um campo ligado à sedução.

6 É interessante observar que durante um longo período da história da cultura ocidental a privacidade era associada ao luxo. 